\title{
El Gueddid, a traditional Algerian dried salted meat: Physico-chemical, microbiological characteristics and proteolysis intensity during its manufacturing process and ripening.
}

Radhia Benlacheheb ${ }^{\mathrm{a}}$, Samira Becila ${ }^{\mathrm{a}}$, Miguel A. Sentandreu ${ }^{\mathrm{b} *}$, Kahina Hafid ${ }^{\mathrm{a}}$, Hiba Boudchicha $^{\mathrm{a}}$ and Abdelghani Boudjellal ${ }^{\mathrm{a}}$

a Institut de Nutrition d'Alimentation et des Technologies Agro-Alimentaires (INATAA). Université des Frées Mentouri. Constantine 1. Algeria.

b Instituto de Agroquimica y Tecnologia de Alimentos, CSIC, Avenida Agustín 7, 46980, Valencia, Spain.

\section{Corresponding author:}

*: Corresponding author: +34 963900022x2103; fax: +34 963636301; e-mail: ciesen@iata.csic.es 


\begin{abstract}
El Gueddid is a traditional salted and dried meat with high popularity in Algeria. It is used as an ingredient in various dishes. In this study, different samples of El Gueddid were analyzed at different processing times to follow up their microbiological and physico-chemical properties. Changes in the protein profile were also demonstrated by electrophoretic study of myofibrillar proteins. Microbiological determinations included the Total Viable Count, Coliforms, Staphylococci, Lactic Acid Bacteria, Yeasts and Moulds, whereas physicochemical properties were characterized by $\mathrm{pH}$ and moisture. The results showed that microbial profiles were elevated for all the studied micro-organisms. Staphylococci and Lactic Acid Bacteria were the most abundant micro-organisms in the product. Total Coliforms were found in low numbers in fresh meat, being eliminated at the post salting stage of process. The physico-chemical characteristics showed that the moisture content decreased in the product during the drying period. The $\mathrm{pH}$ also decreased during the drying period, then remained almost unchanged during the rest of the ripening period. Moreover, El Gueddid showed low water activity and high salt content. One of the most important changes in the profile of myofibrillar proteins was a reduction in the myosin heavy chain content.
\end{abstract}

Key words: meat products, dry-curing, salting, ethnical foods, protein hydrolysis 


\section{Introduction}

Traditional foods constitute a heritage transferred from one generation to another for ages. They represent historical and typical products surrounded by expertise. Traditional foods are consumed locally or regionally and can be considered as an expression of culture, history and lifestyle (Chabbouh et al., 2013). Various traditional meat products have long been known in North African countries, Middle East and Southern Asia. They were made as a means to preserve meat when it was available in large quantities, exceeding immediate needs (Benkerroum, 2013). Several fermented meat products have been analyzed throughout the world, especially in the case of dry-cured ham. With the increasing proliferation of meat products labeling guarantee of origin as a way to assess their quality, there are several renowned dry-cured ham types in the world. Most of them are produced in the South European area such as Spanish "Ibèrico" and "Serrano", Italian "Parma" and "San Danielle", or French "Bayonne" ham (Sentandreu et al., 2007).

El Gueddid is a typical meat product of the Maghreb countries (Algeria, Morocco and Tunisia). The preparation of this product varies from one country to another; however, the same name is kept. In Algeria, this product is still widely used and appreciated. It is a heritage of expertise involving soil, animals, and rural population, which requires protection and conservation as a local biological resource.

El Gueddid can be prepared from lamb meat, beef, or goat meats depending on the geographical area. In Figure 1, the samples used for different analysis were prepared from lamb meat in the region of Constantine. The meat is cut into pieces (flank, leg, shoulder or chops) then salted. There are two main types of salting methods that can be used, dry salting and brining. For dry salting, a mixture of salt and spices such as coriander and pepper are added to a piece of meat, and the latter is left for 12 hours at $4^{\circ} \mathrm{C}$. For brining, the pieces of 
meat are immersed in a solution which contains salt and water. In Tamanrasset (South of Algeria), region, people also add vinegar to the solution. The cut meat is then dried by exposition to the sun by hanging. The obtained product is called El Gueddid. Obtained by this traditional practice, El Gueddid can be stored at room temperature for more than a year (Chabbouh et al., 2013). For consumption, El Gueddid is desalted by immersion in water to make it tender before use in various dishes, such as Couscous, Aiche, Marloga in the region of Ghardaia (the South of Algeria), and Elhessa in the region of Tamanrasset (the South of Algeria). A good preservation of El Gueddid is related to the lowering of the water activity (aw) and salting during processing.

The development of flavor in meat products is a very complex process due to the high number of reactions involved. Proteolysis constitutes the main biochemical reaction affecting flavor and texture of meat products, resulting in a final sensorial quality highly appreciated by consumers (Toldrá, 1998; Kaban, 2013; Prevolnik et al., 2014).

El Gueddid is characterized by a strong flavor due to fat lipolysis and free fatty acid oxidation (Bennani et al., 2000). Proteolysis can also help in flavor development by releasing some amines or amino acids (Lorenzo, 2014). Protein hydrolysis in dry cured ham during dry-cured processing and ripening, together with changes in structural proteins and their relation with texture evolution and flavor perception were studied by many authors (Toldrá, 1998; Sentandreu et al., 2007; Mora et al., 2010; Bermúdez et al., 2014(a), 2014(b); Bermúdez et $a l ., 2015)$. On the other hand, post-mortem proteolysis occurring during dry-cured processing and ripening of El Gueddid is still unknown. In the present work, physicochemical and microbiological characteristics of El Gueddid were studied. In addition, protein separation on polyacrylamide gel electrophoresis was used for monitoring changes in myofibrillar proteins during the manufacturing process of El Gueddid. 


\section{Materials and methods}

\subsection{Samples}

Samples of El Gueddid were collected and prepared in the region of Constantine (North East of Algeria) by a maker using the traditional manner: Fresh lamb meat samples (flank) were taken at $48 \mathrm{~h}$ post mortem. The meat is cut into pieces $(20 \mathrm{~cm} \times 4 \mathrm{~cm} \times 1.33 \mathrm{~cm})$ then salted by brining. The pieces of meat are immersed in a saline solution in a $0.5 \mathrm{w} / \mathrm{v}$ ratio $(500 \mathrm{~g}$ of meat/ $1000 \mathrm{ml}$ of brine solution). The Saline solution was prepared by mixing sodium chloride with water at a salt concentration of $21 \%(\mathrm{w} / \mathrm{w})$. Brined meat samples were stored at $4{ }^{\circ} \mathrm{C}$ for $12 \mathrm{~h}$ according to the traditional conditions of the salting stage. The cut meat is then dried by exposition to the sun at approximately $30^{\circ} \mathrm{C}$ for about 10 days by hanging. After drying, El Gueddid is stored at room temperature (Figure 1). The end of the drying period of El Gueddid was characterized by changes in both the texture of the product, which became harder, and the color of meat. This step corresponded to a level of moisture of $20 \%$.

These samples were analyzed at different times to follow up the physicochemical, microbiological and biochemical properties. Determinations included (In triplicate): Moisture, $\mathrm{pH}$, sodium chloride content and water activity, Total Viable Count, Total Coliforms, Lactic Acid Bacteria, yeasts, moulds, and Staphylococci. Changes in myofibrillar proteins during the manufacturing process of El Gueddid were also assessed as described in section 2.5.

\subsection{Physico-chemical determination}

Moisture content was determined by drying 3 grams of the product at $105^{\circ} \mathrm{C}$ to constant weight (AOAC, 2000). The $\mathrm{pH}$ of samples was measured using a digital $\mathrm{pH}$-meter (BANTE). One gram of each sample was homogenized with $10 \mathrm{ml}$ of distilled water in a polytron at 
22000 rpm (PT-MR 2100) for 15 s (Lorenzo et al., 2008). Sodium chloride content in El Gueddid samples (1 and 12 months after processing) was measured using the ammonium thiocyanate and silver nitrate method with ferrous sulphate as indicator (AOAC, 2000). Water activity $\left(a_{w}\right)$ was measured by $a_{w}$ meter (FA-st1, GBX France Scientific Instrument, France) at $23{ }^{\circ} \mathrm{C} \pm 1{ }^{\circ} \mathrm{C}$ (Table 2).

\subsection{Microbiological determination}

Twenty-five grams of each sample were added aseptically to $225 \mathrm{~mL}$ of sterile buffer peptone water and were homogenized in a polytron homogenizer at $22000 \mathrm{rpm}$ (PT-MR 2100) for $1 \mathrm{~min}$ to prepare the initial dilution (1/10). Appropriate decimal dilutions were prepared in sterile saline water $(0.9 \% \mathrm{NaCl})$ in tubes for microbial enumeration.

Standard Plat Count: Total Viable Counts on Plate Count Agar (PCA) incubated at $30{ }^{\circ} \mathrm{C}$ for 72 h. Total Coliforms were determined on Violet Red Bile Glucose (VRBG), incubated at $37^{\circ} \mathrm{C}$ for $24 \mathrm{~h}$. Lactic Acid Bacteria were determined on Man Rogosa Sharp Agar (MRS) incubated at $30^{\circ} \mathrm{C}$ for $72 \mathrm{~h}$. Yeasts and moulds: They were determined on Oxytetracycline Glucose Agar (OGA) supplemented with $0.1 \mathrm{~g} / \mathrm{L}$ of chloramphenicol, incubated at $25^{\circ} \mathrm{C}$ for 5 days. Staphylococci were determined on Chapman Agar, incubated at $37^{\circ} \mathrm{C}$ for $48 \mathrm{~h}$.

\subsection{Extraction of meat proteins}

Extraction of muscle proteins was carried out as described by Sentandreu, Fraser, Halket, Patel, and Bramley (2010) with some modifications: one gram of each muscle sample was homogenized with $10 \mathrm{ml}$ of $50 \mathrm{mM}$ Tris- $\mathrm{HCl}$ buffer $(\mathrm{pH} 8.0)$ in a Polytron ${ }^{\circledR}$ homogenizer (KINEMATICA AG, Luzern, Switzerland) for $1 \mathrm{~min}$. The homogenate was then centrifuged at $10,000 \mathrm{~g}$ for $20 \mathrm{~min}$ at $4{ }^{\circ} \mathrm{C}$ in an Allegra X-22R centrifuge (Beckman, Fullerton, CA, USA).

The supernatant was collected, constituting the sarcoplasmic protein fraction. The pellet was 
washed in $10 \mathrm{~mL}$ of the same buffer and then homogenized with a vortex for $1 \mathrm{~min}$. After centrifugation at $10,000 \mathrm{~g}$ for $20 \mathrm{~min}$ at $4{ }^{\circ} \mathrm{C}$ in the Allegra X-22R centrifuge, the supernatant was discarded, collecting the precipitate, which was re-dissolved in $10 \mathrm{~mL}$ of $50 \mathrm{mM}$ Tris$\mathrm{HCl}(\mathrm{pH} 8.0)$ containing $6 \mathrm{M}$ urea and $1 \mathrm{M}$ thiourea, and further homogenized in a vortex for $5 \mathrm{~min}$ in order to solubilize myofibrillar proteins. The homogenate was finally centrifuged at $10,000 \mathrm{~g}$ for $10 \mathrm{~min}$ in the Allegra $\mathrm{X}-22 \mathrm{R}$ centrifuge, collecting the supernatant that constituted the myofibrillar protein extract. Myofibrillar extracts were filtered through 0.45 $\mu \mathrm{m}$ membrane filters (Scharlab, Barcelona, Spain) prior to use. Protein concentration of extracts was determined by the method of Bradford (Bradford, 1976).

\subsection{Polyacrylamide gel electrophoresis}

Protein separation was carried out by polyacrylamide gel electrophoresis in reducing and denaturant conditions (SDS PAGE), according to Laemmli (1970) using a separation gel (12\% polyacrylamide) and a stacking gel (4\% polyacrylamide). A volume of $10 \mu \mathrm{L}(1 \mathrm{mg} / \mathrm{mL}$ of protein) of myofibrillar proteins was mixed with $10 \mu \mathrm{L}$ of sample buffer solution $(0.5 \mathrm{M}$ Tris- $\mathrm{HCl} \mathrm{pH} 6.8,50 \% \mathrm{v} / \mathrm{v}$ glycerol, $10 \% \mathrm{w} / \mathrm{v}$ SDS, $0.2 \mathrm{M}$ DTT and $0.05 \%$ bromophenol blue), then heated at $95{ }^{\circ} \mathrm{C}$ for 4 min. Bio-Rad Precision Plus Protein Standards (ref. 1610374) were used as molecular weight markers. Electrophoresis was performed on a SE260 Mighty Small electrophoresis unit (Hoefer, San Francisco, USA) at $220 \mathrm{~V}$ until the front reached the gel baseline. Gels were fixed overnight in a solution containing $30 \%$ ethanol and $10 \%$ acetic acid to be further revealed by silver nitrate as follows: Sensitization for $30 \mathrm{~min}$ in $70 \mathrm{ml}$ Water, $30 \mathrm{ml}$ ethanol, $8 \mathrm{mM}$ sodium thiosulfate and $0.5 \mathrm{M}$ sodium acetate; washing 3 times x 10 min in water; Staining in $0.2 \%$ silver nitrate solution for $30 \mathrm{~min}$ in the dark; washing with water for $1 \mathrm{~min}$ and then color development in a solution containing $230 \mathrm{mM}$ sodium carbonate and $37 \%$ of formaldehyde. Color reaction was stopped with $1 \%$ glycine. 
Proteins and their degradation products were elucidated according to their molecular weights estimated from their relative electrophoretic mobilities compared to the electrophoretic position of the molecular weight standards. The relative amount of each protein band was obtained by densitometry analysis using UN SCAN-IT gel 6.1 software.

\subsection{Statistical analysis:}

In order to study the significant modifications of different parameters between the different sampling points during the manufacturing process of El Gueddid, an analysis of student test was performed, with a confidence interval of $95 \%(\mathrm{P}<0.05)$ using the XLSTAT-Premium software. All assayed parameters at different steps of the traditional process of El Gueddid were analyzed in triplicate.

\section{Results and discussion}

\subsection{Moisture}

Drying as a means of preservation is a very old technique (Cassens, 1994). This process is applied to improve meat stability, since it considerably decreases microbiological activity and minimizes physical and chemical changes during meat storage. Moisture must be reduced to stop or to delay the development of microorganisms in El Gueddid (Chabbouh et al., 2013). Figure 2 shows that during the salting step moisture decreased from $72.18 \% \pm 4.08$ to $64.47 \%$ \pm 2.06 . This decrease in the content of water is largely due to the water loss because of the larger concentration gradient between meat and the brine. The aim of the salting step is mainly meat dehydration. Simple air drying is the most common process used for traditional meat products such as El Gueddid. During drying, moisture decreased faster, and the decreasing speed of water content is $3.92 \%$ /day (from day 1 do day 12 ). The decrease of water content in El Gueddid during this stage was significant $(\mathrm{P}<0.05)$.

According to Cassens (1994), if surface water is not evaporated rapidly enough, meat will collect it, allowing the possibility of undesirable microorganisms to grow. The final water content found at day 12 of preparation was $20.37 \% \pm 0.36$. In relation to this, Bennani et al. 
(2000), established a similar moisture decrease pattern in a Moroccan Gueddid, being the ultimate found value of $20 \%$. In the sixth day of preparation, a slight increase of humidity was found, which can be explained by the drying conditions. The decrease turned slower during the ripening step of El Gueddid compared to the drying step, being the decreasing speed of water content of $0.03 \%$ /day (from day 12 to day 45 ). The decrease of water content in El Gueddid during this stage is non-significant $(\mathrm{P}>0.05)$, so there is a stability of the humidity in the product. In the initial phase of drying, the moisture content of the outer layers decreased, while the inner layers lost water in the later periods (Zukál and Incze, 2010). As reported by Toldrá (2002), the drying rate of some meat products like sausage or ham is affected by several factors. Some of them are intrinsic to the product such as $\mathrm{pH}$ (when $\mathrm{pH}$ drops, meat rapidly dries faster), and the amount of intramuscular fat which can constitute a barrier to water diffusion. The weight of meat is another factor, which contributes to extending the time of drying. Fluctuations observed in moisture during ripening can be explained by the conditions of temperature and relative humidity.

\section{2. $\mathrm{pH}$}

The evolution of $\mathrm{pH}$ through processing of El Gueddid is shown in Figure 3. As can be observed, there is a slight increase of $\mathrm{pH}$, starting at $6.29 \pm 0.14$, to increase to about $6.35 \pm$ 0.11 during the post salting phase. After this, the $\mathrm{pH}$ deceased during the drying period. At the end of this period the $\mathrm{pH}$ value was $5.95 \pm 0,032$ and the decreasing speed of $\mathrm{pH}$ in this phase is 0.03 units/day. This decrease in $\mathrm{pH}$ is related to the accumulation of lactic acid produced by lactic acid bacteria during El Gueddid preparation (Table 1). $\mathrm{pH}$ reduction prevents the growth of undesirable microflora like pathogenic and spoilage microorganisms. As shown in Figure 3, pH remained almost unchanged during the ripening period (The decreasing speed of $\mathrm{pH}$ in this phase is 0.01 units/day, from day 12 to day 45). However, $\mathrm{pH}$ may increase during the ripening period due to the formation of basic compounds, probably as a result of 
proteolysis (Spaziani et al., 2009; Kaban, 2013). During the different stages of manufacturing of El Gueddid, the changes in the $\mathrm{pH}$ were non-significant $(\mathrm{P}>0.05)$.

\subsection{Sodium chloride content:}

Salt is the main curing agent. It has several roles in the final quality of meat product, an effect on microbiological, physicochimical and sensorial characteristics (Toldrá, 2002). Results showed a sodium chloride content in the range of $12.86 \% \pm 1.18$ in El Gueddid ready to eat, (obtained after one month of elaboration). Salt content found in El Gueddid after one year of storage increased to a value of $17.93 \% \pm 0.06$ (Table 2). These data are in accordance with previous published data where salt content was found between $7.43 \%$ and $12.40 \%$ for Moroccan Gueddid (Bennani et al., 1995). These results are higher than data found for dry biltong (5.5-7.9\%). These high salt values can be explained by the high brine salt concentration used during processing. One of the main roles of salt is the decrease in water activity, but it exerts also remarkable effects in both the solubility and degradation of myofibrillar proteins (Chabbouh et al., 2012).

\subsection{Water activity (aw)}

Kinetics of chemical, enzymatic and microbial reactions are dependent on water activity (Toldrá, 2002). The obtained results showed an average water activity value of $0.48 \pm 0.02$ for El Gueddid ready to eat. For El Gueddid stored after one year, $a_{w}$ was in the range of $0.72 \pm$ 0.03 (Table 2). These results are coherent with data found in Moroccan Gueddid by Bennani et al., (1995). These authors reported a value of water activity in the average of $0.54 \pm 0.06$. Our results are in accordance to those found by Petit et al., (2014) for dry biltong, for which they reported $a_{w}$ values of in the range of $0.65-0.68$. According to data reported by Bennani et al., (1995), and Petit et al., (2014), El Gueddid can be classified as an intermediate moisture 
food. The low $\mathrm{a}_{\mathrm{w}}$ found can be explained by the combined employ of drying/salting steps during the elaboration process of El Gueddid (Bennani et al., 1995).

\subsection{Microbiological characteristics}

The microbial profiles of El Gueddid during the different processing steps are plotted in Table 1. The Total Viable Count level in El Gueddid changed from $7.24 \times 10^{5} \mathrm{cfu} / \mathrm{g}$ (in fresh meat to reach numbers around $10^{6} \mathrm{cfu} / \mathrm{g}$ during ripening stage. This result would indicate the presence of a high level of fermentative bacteria, which is in agreement with the result found by Petit et al., (2014). It is assumed that coliforms determine the sanitary conditions of food handling and manipulation. In the present work, Total Coliforms were found in low numbers in fresh meat, then being eliminated after 3 days. This result is coherent with data found by Boudchicha et al. (2017) during the preparation of Khliaa Ezir (a traditional cured meat product of Algeria). This may be due to the dual action of salting and drying. As reported by Lorenzo et al. (2015), $\mathrm{NaCl}$ induce selective multiplication of salt-tolerant bacteria and Lactic Acid Bacteria, while suppressing the growth of coliforms.

Staphylococci and Lactic Acid Bacteria were between the most abundant micro-organisms in the product, together with yeast (Table 1). Staphylococci are halophilic micro-organisms that may survive in high salt concentrations. They were not detected in raw material prior to El Gueddid preparation. After salting, the results showed a rapid increase to reach high levels during the ripening stage $\left(7.94 \times 10^{7} \mathrm{cfu} / \mathrm{g}\right)$, above the Staphylococci level of $6.2 \times 10^{5} \mathrm{cfu} / \mathrm{g}$ determined in El Gueddid in previous works (Bennani et al., 2000). These rates exceeded the Algerian standard of $5 \times 10^{3} \mathrm{cfu} / \mathrm{g}$ (JOURNAL OFFICIEL DE LA REPUBLIQUE ALGERIENNE, 2017). It is assumed that, when level of staphylococci reach $10^{6} \mathrm{cfu} / \mathrm{g}$, the food is considered as potentially hazardous. High contamination by Staphylococcus aureus 
could indicate a possible production of thermostable enterotoxin. However, the high salt concentration in $\mathrm{El}$ Gueddid (average value of $\mathrm{NaCl}$ in $\mathrm{El}$ Gueddid was $12.86 \pm 1.18 \%$ ) together with the low water activity (average value of $a_{w}$ in El Gueddid was $0.72 \pm 0.03$ ) will constitute an effective barrier to this risk. In that respect, Pedrosa et al. (2014) reported minimum values of water activity ranging from $0.93-0.86$ to preclude the production of this enterotoxin, which is the case of EL Gueddid (Table 2). On the other hand, and according to Chabouh et al (2012), a salt concentration higher than 10\% can delay microbial growth. In this subsection, there are no recommended standards for Lactic Acid Bacteria. However, results obtained are coherent with data published by Bennani et al., (2000) and petit et al., (2014). Both of them reported the presence of a high level of fermentative bacteria in the analyzed products.

Lactic Acid Bacteria (LAB) and yeasts were also found in El Gueddid (Table 1). These microorganisms were revealed to exist in high numbers, $1.54 \times 10^{7}$ and $2.81 \times 10^{7} \mathrm{cfu} / \mathrm{g}$ during the ripening stage, respectively. The elevated counts of LAB contribute to the $\mathrm{pH}$ decrease in El Gueddid, which can help to delay the growth of undesirable microorganisms. In a previous study (Essid et al., 2013), strains of Lactic Acid Bacteria and Staphylococci were isolated from a Tunisian Gueddid to be used as starters for the manufacture of a dry fermented sausage. According to Fonseca et al. (2013), growth of Lactic Acid Bacteria and Staphylococci during ripening is important to set the final sensorial, safety and nutritional characteristics of dry fermented meat products.

Yeasts are the most tolerant microorganisms to high salt concentrations and to low aw values. In fermented meats, they contribute to the final flavor by their proteolytic and lipolytic activity (Toldrá, 2002). Compared to moulds, the obtained results showed a strong predominance of yeasts, showing agreement with results found by Petit et al. (2014), In El Gueddid, the presence of some yeast could have a role in the biochemical processing through 
the release of lipases and/or proteases into the product during the ripening period, as reported by Bennani et al. (1995).

\subsection{Proteolysis}

Protein profiles of El Gueddid myofibrillar proteins during both drying and ripening stages are shown in Figure 4 and 5. Muscle proteolysis is the most important phenomenon occurring during both meat aging and dry-curing (Sentandreu et al., 2007). The main enzymes responsible for the degradation of muscle proteins during dry-curing are endopeptidases, mainly calpains and cathepsins. Exopeptidases degrade the large polypeptides generated by endopeptidases (Mora et al., 2013). Toldrá (2002) reported that proteolysis has a high impact in the quality of dry-cured ham characteristics such as texture, by breakdown of the myofibrillar proteins, together with the generation of peptides and free amino acids that will have a strong influence on the final taste and aroma profile. Other authors such as Kaban (2013) observed that proteolysis is an important phenomenon during pastirma processing with consequences for the final sensory quality. For El Gueddid, Bennani et al.(1995), together with Chabbouh et al. (2012), think that proteolysis during ripening and curing may give rise to some flavor compounds that improve the organoleptic characteristics of this product.

In Figure 4, the electrophoretic profile of El Gueddid myofibrillar proteins at the end of drying and ripening stages displayed the following: At day 27 of ripening (Lane G), there was an increase of bands in the range about 180 - $140 \mathrm{kDa}$ (Band group $1 \mathrm{in}$, Figure 4). These results can be explained by the proteolysis of myosin heavy chain. This observation is in agreement with the one reported by Chabbouh et al. (2012) in Tunisian Gueddid. In the same line, Spaziani et al. (2009), reported a decrease in myosin heavy chain during the ripening of dry sausages and the increase of a $145 \mathrm{kDa}$ band throughout ripening. Also, at day 24 of ripening of El Gueddid, a decrease in the intensity of a protein band with molecular weight of 
about $37 \mathrm{kDa}$ was observed (Band 2, Figure 4). In Figure 5, the disappearance of proteins bands was observed in the range $85-73 \mathrm{kDa}$ at the beginning of the ripening stage (Band group 3, Figure 5), together with a decrease of the intensity of proteins bands around $33 \mathrm{kDa}$ (Band group 4, Figure 5) and $14 \mathrm{kDa}$ (Band 5, Figure 5). The intense $42 \mathrm{kDa}$ protein band (Band 6, Figure 5), ascribed to be actin (Ouali et al., 2013), showed also a decrease in intensity during the whole process, though this is not so evident due to the high amount of this protein in each gel lane.

\section{Conclusion}

During the processing of El Gueddid, there is a decrease in moisture content and $\mathrm{pH}$. The reduction of water content is faster during the first period of drying. The decrease was slower during the following days. The $\mathrm{pH}$ deceased during the drying period. This decrease can be related to the accumulation of lactic acid produced by Lactic Acid Bacteria in the product. Staphylococci and Lactic Acid Bacteria were abundant in the product. Coliforms were found in low numbers in fresh meat, and then were eliminated during post-salting stage. The physico-chemical characteristics showed that the moisture content decreased in the product during the drying period. The $\mathrm{pH}$ also decreased during the drying period, then remained almost unchanged during the rest of the ripening period. El Gueddid showed a low water activity and high salt content. The most important changes in the profile of myofibrillar proteins showed the increase of bands in the ranges of $180-140 \mathrm{kDa}$, a decrease in the intensity of a protein band with molecular weight of about $37 \mathrm{kDa}$, the disappearance of proteins bands of about $85-73 \mathrm{kDa}$ at the beginning of the ripening stage and a decrease of the intensity of proteins bands of 33 and $14 \mathrm{kDa}$. A decrease in the intensity of actin during the whole process was also evident despite the high amount of this protein in the myofibrillar extract. The present obtained results related to the proteolysis carried out during the 
processing of El Gueddid will have to be further refined by mass spectrometry approaches in near future, a step that is necessary for a complete characterization of both protein substrates and naturally generated peptides during El Gueddid processing.

\section{Acknowldedgements}

The authors are grateful to: Project AGL2012-32146 from the Spanish Ministry of Economy and Competitiveness is fully acknowledged. Special thanks to the institute of Agrochemistry and Food Technology (CSIC), Valencia (Spain).

\section{REFERENCES}

AOAC (2000). Official methods of analysis (17th edition). Washington, DC: Association of Official Analytical Chemists.

Benkerroum N. (2013). Traditional Fermented Foods of North African Countries: Technology and Food Safety.Challenges with Regard to Microbiological Risks. Comprehensive Reviews in Food Science and Food Safety 12: 54-89.

Bennani L, Zenati Y, Faid M and Ettayebi M. (1995). Physico-chimical and microbiological characteristics of a dried salted meat product (Kaddid) in Morocco. Zeitschrift für Lebensmittel-Untersuchung und-Forschung 201: 528-532.

Bennani L, Faid M and Bouseta A. (2000). Experimental manufacturing of kaddid, a salted dried meat product: control of the microorganisms. European Food Research and Technology 211: 153-157.

Bermúdez R, Franco D, Carballo J and Lorenzo JM. (2014a). Physicochemical changes during manufacture and final sensory characteristics of dry-cured Celta ham. Effect of 
muscle type. Food Control 43: 263-269.

Bermúdez R, Franco D, Carballo J, Sentandreu MA and Lorenzo JM. (2014b). Influence of muscle type on the evolution of free amino acids and sarcoplasmic and myofibrillar proteins through the manufacturing process of Celta dry-cured ham. Food Research International 56: 226235.

Bermúdez R, Franco D, Carballo J and Lorenzo JM. (2015). Influence of type of muscle on volatile compounds throughout the manufacture of Celta dry-cured ham. Food Science and Technology International 21: 581-592.

Bradford MM. (1976). Rapid and sensitive method for quantification of microgram quantities of protein utilizing principle of protein-dye binding. Analytical Biochemistry 72: 248-254.

Boudechicha HR, Nasril I, Bennaceur Z, Sellama M, Hafid K, Boudjellal A and Gagaoua M. (2017). Microbiological changes during the preparation steps of Khliaa Ezir: a traditional cured meat product of Algeria. Integrative Food, Nutrition and Metabolism 4(6): 1-5.

Chabbouh M, Ben Hadj Ahmed S, Farhat A, Ali Sahli A and Bellagha S. (2012). Studies on the Salting Step of Tunisian Kaddid Meat: Experimental Kinetics, Modeling and Quality. Food Bioprocess and Technology 5: 1882-1895.

Chabbouh M, Sahlia A and Bellaghaa S. (2013). Does the spicing step affect the quality and drying behaviour of traditional kaddid, a Tunisian cured meat? Journal of the Science of Food and Agriculture 93: 3634-3641.

Cassens RG. (1994). Meat preservation. Preventing losses and assuring safety. Trumbull, Conn: Food \& Nutrition Press.

Essid I and Mnasser H. (2013). Effect of inoculation of selected Staphylococcus xylosus and Lactobacillus plantarum strains on biochemical, microbiological and textural characteristics of a Tunisian dry fermented sausage. Food Control 32: 707-714.

Fonseca S, Cachaldora A, Gómez M, Franco I and Carballo J. (2013). Monitoring the bacterial population dynamics during the ripening of Galician chorizo, a traditional dry 
fermented Spanish sausage. Food Microbiology 33: 77-84.

JOURNAL OFFICIEL DE LA REPUBLIQUE ALGERIENNE №39 (2017). Arrêté interministériel du 2 Moharram 1438 correspondant au 4 octobre 2016 fixant les critères microbiologiques des denrées alimentaires. Viandes rouges et dérivés.

Laemmli, UK. (1970). Cleavage of structural proteins during the assembly of the head of bacteriophage T4. Nature 227: 680-685.

Lorenzo JM, García Fontán MC, Franco I and Carballo J. (2008). Biochemical characteristics of dry-cured lacón (a Spanish traditional meat product) throughout the manufacture, and sensorial properties of the final product. Effect of some additives. Food Control 19(12): 1148-1158.

Lorenzo JM, Bermúdez R, Domínguez R, Guiotto A, Franco D and Purriñnos L. (2015). Physicochemical and microbial changes during the manufacturing process of dry-cured lacon salted with potassium, calcium and magnesium chloride as a partial replacement for sodium chloride. Food Control 50: 763-769.

Kaban G. (2013). Sucuk and pastirma: Microbiological changes and formation of volatile compounds. Meat science 95: 912-918.

Mora L, Sentandreu MA and Toldrá F. (2010). Identification of small troponin T peptides generated in dry-cured ham. Food Chemistry 123: 691-697.

Mora L, Fraser PD and Toldrá F. (2013). Proteolysis follow-up in dry-cured meat products through proteomic approaches. Food Research Internationa 54: 1292-1297.

Ouali A, Gagaoua M, Boudida Y, Becila S, Boudjellal A, Herrera-Mendez CH and Sentandreu MA. (2013). Biomarkers of meat tenderness: Present knowledge and perspectives in regards to our current understanding of the mechanisms involved. Meat Science 95: 854-870.

Pedrosa NdA, Madruga MS, Costa RG, Medeiros GR, Duarte TF, Voltolini TV and Martins 
SS. (2014). Salted lamb meat blanket of Petrolina-Pernambuco, Brazil: Process and quality. Food Science and Technology 34: 44-50.

Prevolnik M, Andronikov D, Žlender B, Font-i-Furnols M, Novič M, Škorjanc D and ČandekPotokar M. (2014). Classification of dry-cured hams according to the maturation time using near infrared spectra and artificial neural networks. Meat Science 96 : 14-20.

Petit T, Caro Y, Petit AS, Santchurn SJ and Collignan A. (2014). Physicochemical and microbiological characteristics of biltong, a traditional salted dried meat of South Africa, Meat Science 96: 1313-1317.

Sentandreu MA, Armenteros M, Calvete JJ, Ouali A, Aristoy MC and Toldrá F. (2007). Proteomic Identification of Actin-Derived Oligopeptides in Dry-Cured Ham. Journal of Agricultural and Food Chemistry 55: 3613-3619.

Sentandreu MA, Fraser PD, Halket J, Patel R and Bramley PM. (2010). A Proteomic-Based Approach for Detection of Chicken in Meat Mixes. Journal of Proteome Research 9: 3374-3383.

Spaziani M, Del Torre M and Stecchini ML. (2009). Changes of physicochemical, microbiological, and textural properties during ripening of Italian low-acid sausages. Proteolysis, sensory and volatile profiles Italy. Meat Science 81: 77-85.

Toldrá F. (1998). Proteolysis and Lipolysis in Flavour Development of Dry-cured Meat Products. Meat Science 49(1): S101-S110.

Toldrá F. (2002). Dry-cured meat products. Trumbull, Conn: Food \& Nutrition Press.

Zukál E and Incze K. (2010). Drying. In Toldra F. Handbook of Meat Processing. Hoboken, NJ: John Wiley. 


\section{FIGURES CAPTIONS}

Figure 1. Traditional preparation process of Algerian Gueddid.

Figure 2. Evolution of moisture throughout the manufacture and ripening of El Gueddid

Figure 3. $\mathrm{pH}$ decrease pattern throughout the manufacture and ripening of El Gueddid

Figure 4. SDS-PAGE (8\%) profile of myofibrillar proteins throughout the manufacture of El Gueddid. Day 9 (A), day 12 (B), day 15 (C), day 18 (D), day 21 (E), day 24 (F), day $27(\mathrm{G})$, day $30(\mathrm{H})$, day $33(\mathrm{I})$, day $36(\mathrm{~J})$, day $39(\mathrm{~K})$, day $42(\mathrm{~L})$, day $45(\mathrm{M})$.

Figure 5. SDS-PAGE (12\%) profile of myofibrillar proteins throughout the manufacture of El Gueddid. Day 9 (A), day 12 (B), day 15 (C), day 18 (D), day 21 (E), day 24 (F), day 27 (G), day $30(\mathrm{H})$, day $33(\mathrm{I})$, day $36(\mathrm{~J})$, day $39(\mathrm{~K})$, day $42(\mathrm{~L})$, day $45(\mathrm{M})$. 
Table 1. Evolution of microbial counts in El Gueddid During processing and ripening.

\begin{tabular}{lcccc}
\hline Microbial group & \multicolumn{4}{c}{ Processing step } \\
(cfu/g) & Fresh meat & After salting & Drying stage & Ripening Stage \\
Standard Plat Count & $7.24 \times 10^{5}$ & $10^{6}$ & $2 \times 10^{5}$ & $1^{6}$ \\
Total Coliforms & $7 \times 10^{3}$ & $\mathrm{a}$ & $\mathrm{a}$ & $\mathrm{a}$ \\
Lactic Acid Bacteria & $\mathrm{a}$ & $2.18 \times 10^{6}$ & $1.77 \times 10^{6}$ & $1.54 \times 10^{7}$ \\
Yeasts & $\mathrm{a}$ & $2.81 \times 10^{7}$ & $4.36 \times 10^{6}$ & $2.81 \times 10^{7}$ \\
Moulds & $\mathrm{a}$ & $\mathrm{a}$ & $\mathrm{a}$ & $\mathrm{a}$ \\
Staphyloccoci & $\mathrm{a}$ & $\mathbf{6 . 1 6 \times 1 0 ^ { 7 }}$ & $\mathbf{2 . 1 8 \times 1 0 ^ { 7 }}$ & $\mathbf{7 . 9 4 \times 1 0 ^ { 7 }}$ \\
\hline a: Not found & & &
\end{tabular}

a: Not found 
Table 2. Physicochemical parameters $\mathrm{NaCl}$ and $\mathrm{a}_{\mathrm{w}}$ determined for $\mathrm{El} \mathrm{Gueddid} \mathrm{at} \mathrm{both} 1$ and 12 months after processing. Comparison with data reported for other dry-cured meat products.

\begin{tabular}{|l|l|l|l|l|l|}
\hline \multicolumn{2}{|c|}{ El Gueddid } & $\begin{array}{l}\text { Moroccan } \\
\text { Gueddid } \\
\text { (Bennani et } \\
\text { al. 1995) }\end{array}$ & $\begin{array}{l}\text { Biltong } \\
\text { (Petit et } \\
\text { al. 2014) }\end{array}$ & $\begin{array}{l}\text { Blanket of } \\
\text { Petrolina- } \\
\text { Pernambuco, } \\
\text { Brazil } \\
\text { (Pedrosa et al. } \\
\text { 2014) }\end{array}$ \\
\hline $\mathrm{NaCl}(\%)$ & $12.86 \pm 1.18$ & $17.93 \pm 0.06$ & $10.21 \pm 1.68$ & $5.5-7.9$ & $1.72-2.5$ \\
\hline $\mathrm{A}_{\mathrm{w}}$ & $0.72 \pm 0.03$ & $0.48 \pm 0.02$ & $0.54 \pm 0.06$ & $0.65-0.68$ & $0.97 \pm 0.02$ \\
\hline
\end{tabular}


Figure 1.

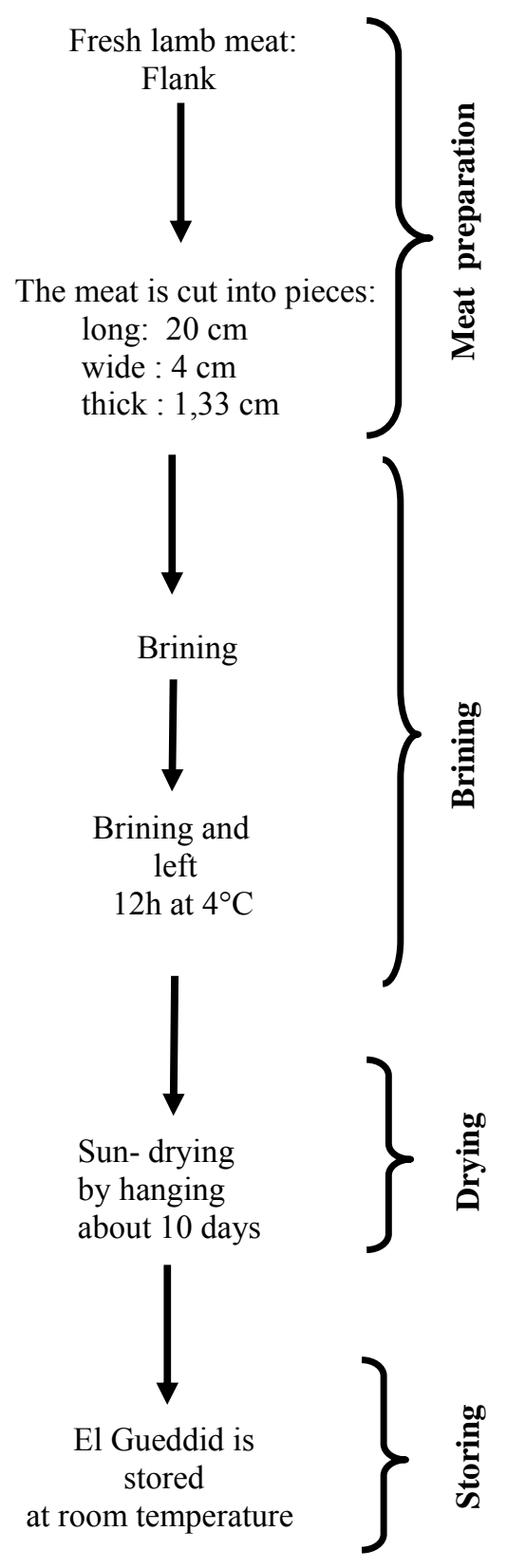


Figure 2.

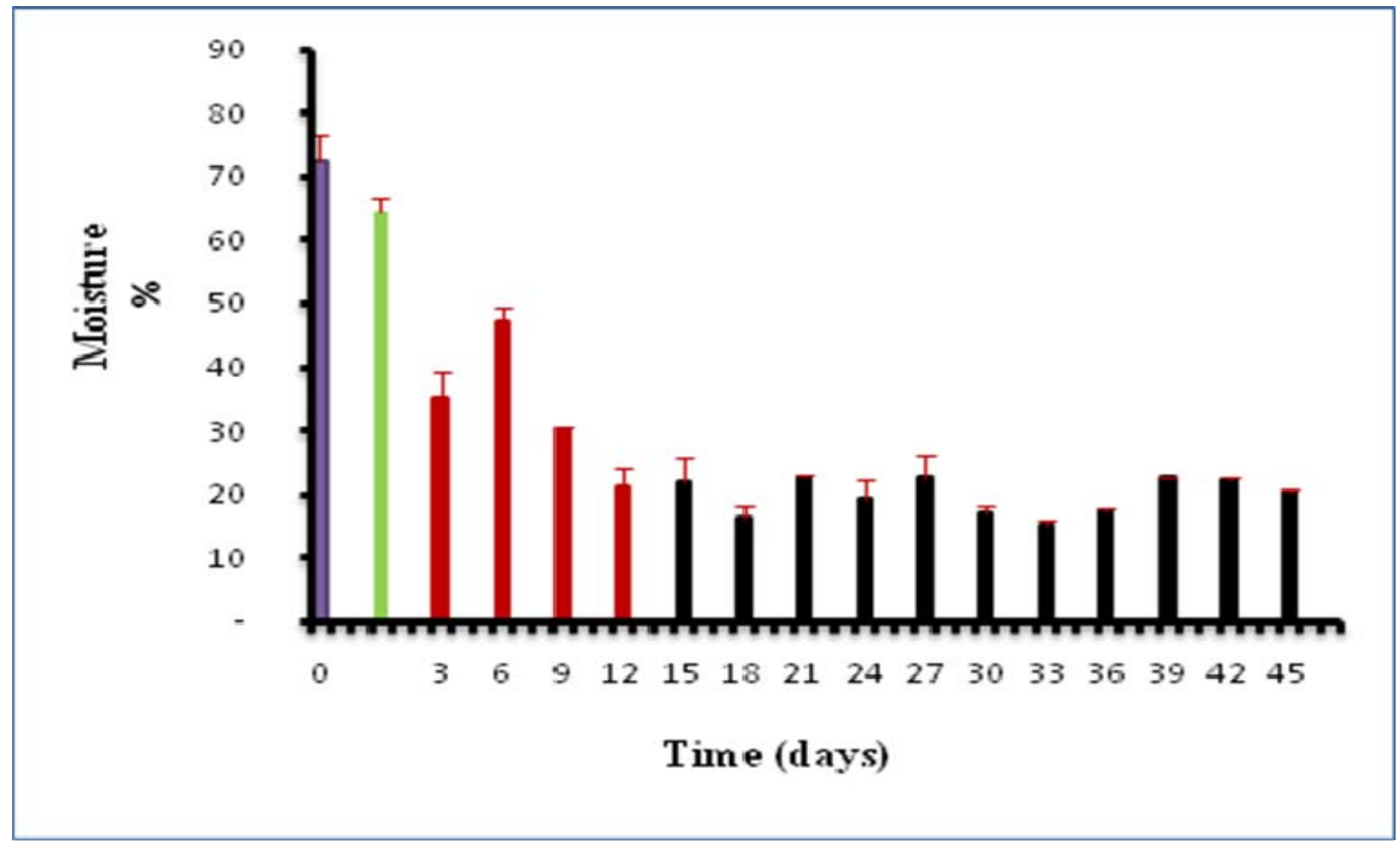

Fresh meat

Salting

Dryine stage

Ripenine stage 
Figure 3.

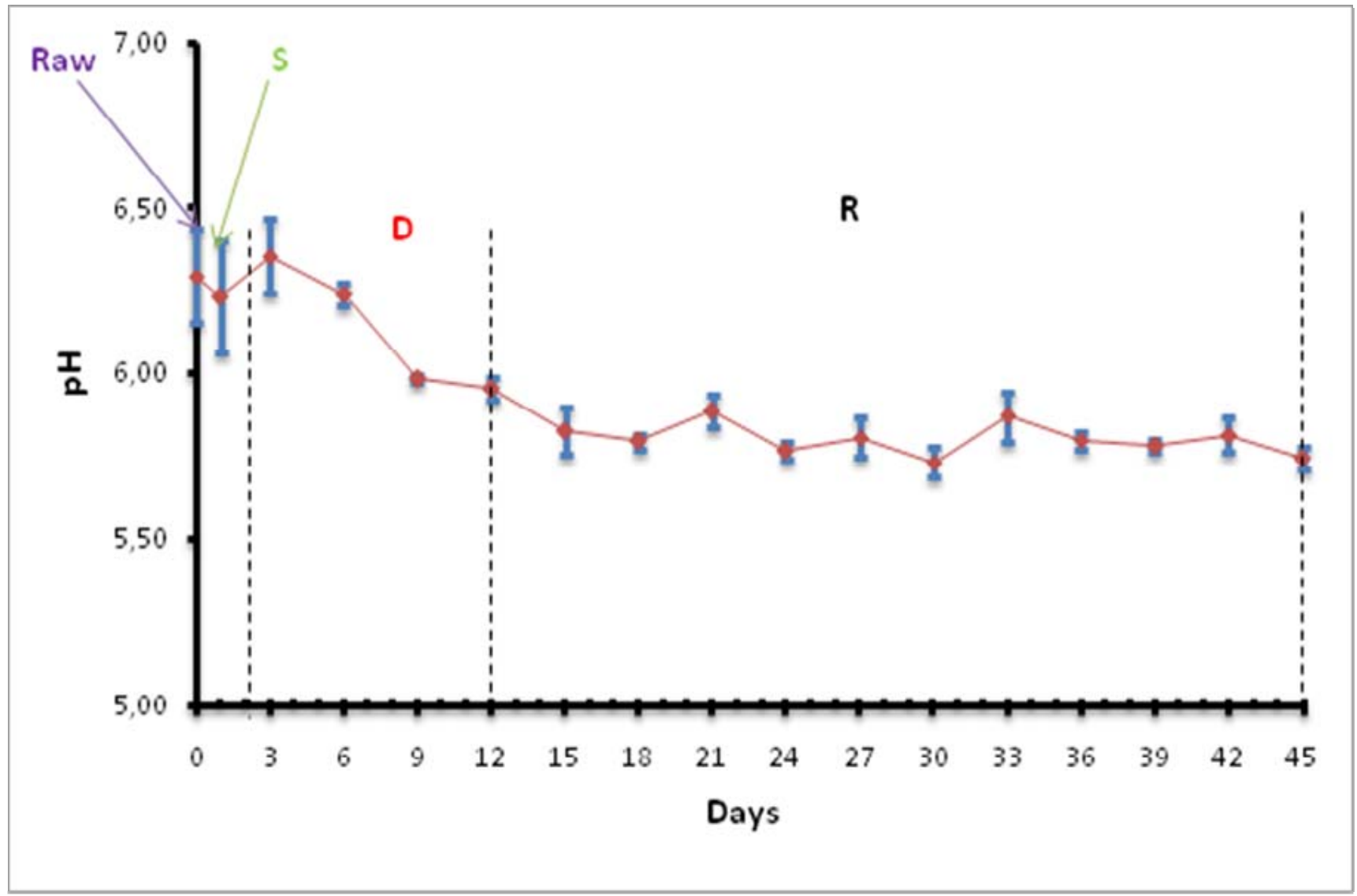

Raw: Fresh meat 


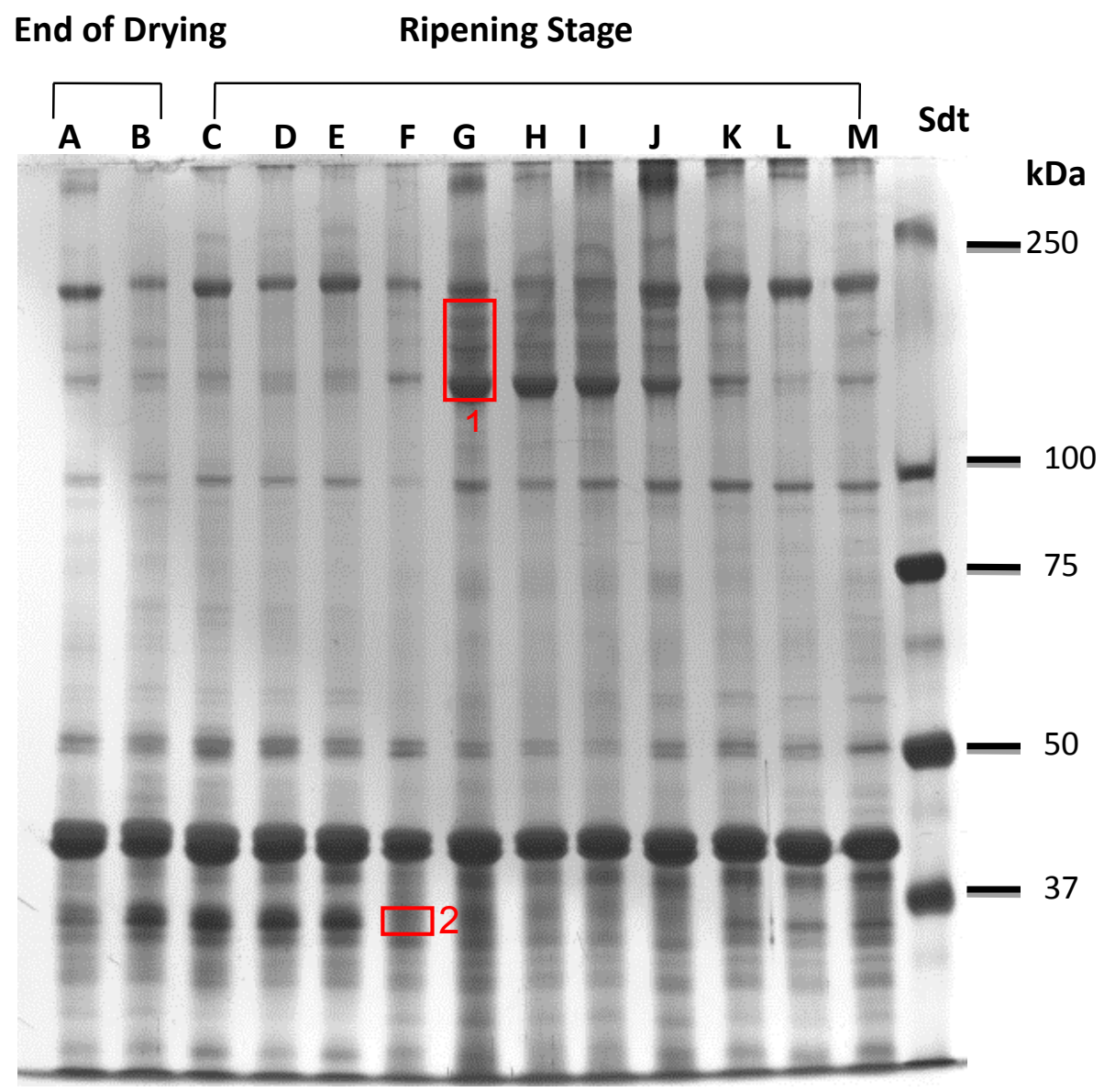




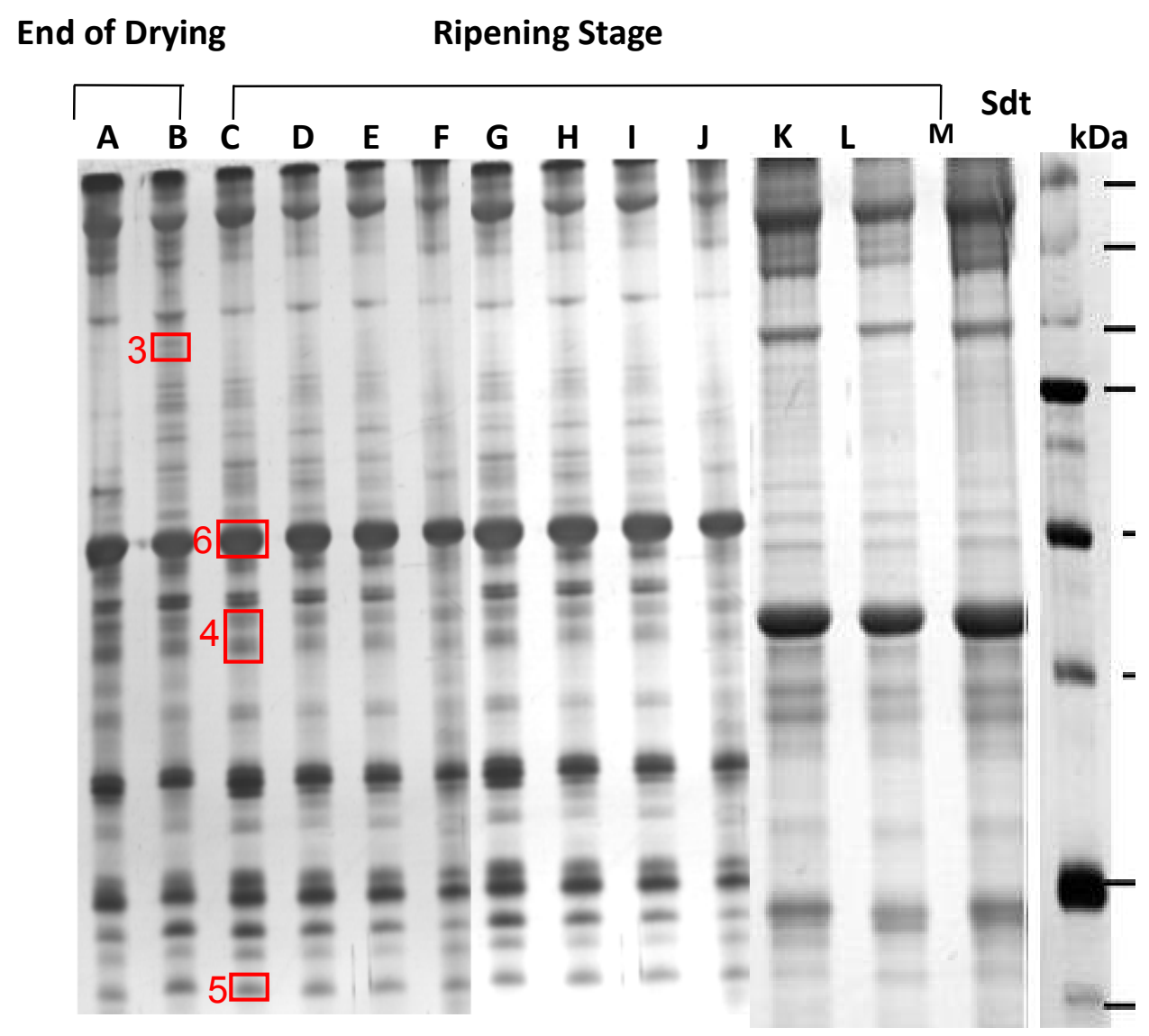

